\title{
Autoimuninis encefalomielitas (MOG asocijuotas) su aktyvia ligos dinamika vaizdiniuose tyrimuose ir minimalia klinikine simptomatika
}

\author{
E. Tilindytè* \\ I. Muliuolis* \\ R. Samaitiené $\dot{e}^{* *}$ \\ *Vilniaus universiteto \\ Medicinos fakultetas \\ **Vilniaus universiteto \\ Medicinos fakultetas; \\ Vaiku ligonine, viešosios \\ istaigos Vilniaus universiteto \\ ligoninès Santaros kliniku filialas
}

\begin{abstract}
Santrauka. Anti-MOG asocijuotas encefalomielitas yra uždegiminė demielinizuojanti liga, kurios metu paciento serume nustatomi autoantikūnai prieš mielino oligodendrocitu glikoproteiną (MOG). MOG spektro susirgimams priskiriamos šios patologijos: optinis neuritas, mielitas, smegenų arba smegenų kamieno encefalitas ir ūminis diseminuotas encefalomielitas. Dažniausiai liga pirmą kartą manifestuoja kaip ūminis diseminuotas encefalomielitas, rečiau - kaip optinis neuritas. Būdinga progresuojanti encefalopatija ir įvairialypè židininė neurologinè simptomatika: dirglumas, sąmonès sutrikimas, silpnumas, sensorikos sutrikimai, tuštinimosi, šlapimo pūslès disfunkcija, spazmiškumas, hiperrefleksija, teigiamas Babinskio refleksas, parezès, smegenèlių ataksija, galvinių nervų neuropatijos, nugaros smegenų disfunkcija (skersinis mielitas). Gydymui naudojami gliukokortikoidai, dažniausiai stebimas greitas atsakas. Jei ligos eiga recidyvuojanti, siūloma gydyti intraveniniu imunoglobulinu, azatioprinu, mikofenolato mofetiliu, rituksimabu.

Straipsnyje aprašoma 6 metų paciente, serganti MOG spektro daugiafaziu diseminuotu encefalomielitu. Ligos pradžia buvo poūmè: pirmiausia mergaitè tapo mieguista dienos metu, per mẻnesįi išsivystė skausmas stovint, dèl kurio liovėsi vaikščioti, dar po kelių dienų atsirado šlapimo susilaikymas, dẻl kurio pacientẻ buvo hospitalizuota. Diagnozė patvirtinta remiantis galvos ir kaklo magnetinio rezonanso tyrimais (MRT) bei MOG antikūnų serume tyrimu. Skyrus gydymą metilprednizolono pulsterapija ir prednizolonu, klinikiné simptomatika išnyko per keletą savaičių. Tačiau šis gydymas buvo nepakankamai efektyvus - nors vaizdiniuose tyrimuose buvo stebimas smegenų pažeidimų regresas, nepavyko išvengti naujų židinių atsiradimo. Kartojant MRT, stebèta recidyvuojanti ligos eiga, tačiau be klinikinių simptomų atsinaujinimo. Recidyvams gydyti buvo skirtas kasmėnesinis intraveninio imunoglobulino kursas (IVIG), iš viso 5 kartus. Gydymas intraveniniais imunoglobulinais buvo efektyvesnis, nes stebėtas pažeidimo židinių regresavimas MRT ir ilgesnè ligos remisija. Tačiau, baigus gydymą, išsivystẻ ligos paūmèjimas, kuris pasireiškẻ atsinaujinusia klinikine simptomatika ir naujų židinių atsiradimu MRT, todèl peršasi išvada, kad gydymas IVIG buvo nepakankamai ilgas.
\end{abstract}

Raktažodžiai: autoimuninis encefalomielitas, anti-MOG asocijuotas encefalomielitas, MOG-IgG tyrimas, demielinizuojanti centrinės nervų sistemos liga.

\section{Adresas:}

Rūta Samaitienè

Vaikų ligoninè, VšI Vilniaus universiteto ligoninès

Santaros kliniku filialas, Vaiku neurologijos skyrius

Santariškiu g. 4, LT-08661 Vilnius

El.paštas ruta.samaitiene@santa.lt

\section{IVADAS}

Mielino oligodendrocitu glikoproteinas (MOG) yra baltymas, išimtinai ekspresuojamas centrinès nervų sistemos oligodendrocitų ir mielino paviršiuje [1]. Antikūnai, nukreipti prieš MOG, buvo nustatyti tiriant ligonius, kuriems diagnozuota išsètinè sklerozė (IS), remiantis būdingais klinikiniais ir radiologiniais požymiais [2]. Dẻl šios priežasties ilgą laiką buvo manoma, kad anti-MOG dalyvauja IS patogenezè-

(C) Neurologijos seminarai, 2019. Open Access. This article is distributed under the terms of the Creative Commons Attribution 4.0 International License CC-BY 4.0 (http://creativecommons.org/licenses/by/4.0/), which permits unrestricted use, distribution, and reproduction in any medium, provided you give appropriate credit to the original author(s) and the source, provide a link to the Creative Commons license, and indicate if changes were made. 
je, ir pacientams, kurių serume nustatytas anti-MOG titras, buvo diagnozuojama IS [2]. Tačiau, atliekant išsamesnius, naujos kartos ląstelinius (angl. cell-based) tyrimus, siekiant išsiaiškinti tikslų anti-MOG veikimo mechanizmą IS patogenezejje, pastebèta, kad aukšti anti-MOG titrai labiau koreliuoja su vaikysteje pasireiškiančiais optinio neurito $(\mathrm{ON})$, mielito, smegenu kamieno encefalito ir ūmaus diseminuoto encefalomielito (ŪDEM) požymiais, nei su klasikine IS [3]. Minèti požymiai pasireiškia dèl demielinizacijos, kurios etiologija gali būti įvairi, tad jie būdingi ir esant kliniškai izoliuotiems sindromams (CIS), kurie laikomi ankstyvuoju IS pasireiškimu [4]. Trys CIS sindromai, kurie dažniausiai stebimi tuo pačiu metu, kada nustatoma IS diagnozė, apima tuos, kurių metu radiologiškai stebimas pažeistas n. opticus, kamienas ir nugaros smegenys [5]. Radiologiškai antiMOG spektro ligos pasireiškia labai panašiai, klinika taip pat reikšmingai nesiskiria, todèl būtent anti-MOG seropozityvumas padeda atskirti anti-MOG spektro ligas nuo CIS [6]. Daugèjant įrodymų, kad anti-MOG ryšys su IS yra silpnesnis, nei manyta anksčiau, anti-MOG spektras yra išskirtas, kaip atskiras nuo IS nozologinis vienetas [7, 8].

Nauji anti-MOG serume nustatymo būdai atvėrẻ kelią tikslesniam demielinizuojančių ligų supratimui ir diferencijavimui. Atskyrus anti-MOG spektro ligas nuo IS, jos dažniau ịtraukiamos ị diferencinę diagnostiką ir dažniau skiriamas tyrimas minėtiems antikūnams (Ak) nustatyti, todèl daugèja aprašytų šios ligos atvejų. Vis dẻlto, atlikti visuotinę patikrą (angl. screening), tiriant retus biomarkerius, netikslinga, nes tai mažintų teigiamą prognostinę šių diagnostinių testų vertę, didejjant klaidingai teigiamų rezultatų kiekiui [3]. Kol kas dar nèra patvirtintų tarptautinių diagnostikos ir gydymo algoritmų, tačiau, remiantis parengtomis tarptautinėmis rekomendacijomis, MOG-IgG siūloma tirti: a) pacientams su monofaziniu ar recidyvuojančiu ūmiu optiniu neuritu, mielitu, smegenų kamieno encefalitu, encefalitu ar jų deriniu; b) jei yra radiologinių ar elektrofiziologinių smegenų demielinizacijos požymių; c) jei yra kitų požymių, susijusių su MRT, fundoskopija, cerebrospinalinio skysčio pakitimais, klinikiniais požymiais, histopatologija, atsaku ic gydymą [3]. Indikacijos MOG-IgG testuoti vaikams, sergantiems igyta demielinizuojančia liga, nèra tokios griežtos, nes šis susirgimas vaikystèje daug dažnesnis [3].

MRT vaizduose MOG-IgG mielitui būdingi keli išskirtiniai požymiai - dažniausiai pilkojoje medžiagoje apriboti pakitimai (sagitalinè linija ir H ženklas) bei jų polinkis nekaupti kontrasto. T2 sekoje stebimi dauginiai, išilginiai, nesusijungiantys pažeidimai nugaros smegenyse ir dažnai stebimas smegenų kūgio pažeidimas nesiskiria nuo IS būdingų radiologinių pakitimų [9].

Šiandien rekomenduojama MOG asocijuotą encefalomielitą diagnozuoti pagal šiuos kriterijus: 1) pasireiškia monofazinis ar recidyvuojantis optinis neuritas, mielitas, smegenų ar smegenų kamieno encefalomielitas arba bet koks šių patologijų derinys; 2) MRT ar elektrofiziologiniai pakitimai atitinka CNS demielinizaciją; 3) nustatytas seropozityvumas MOG-IgG naujos kartos ląsteliniais tyrimais, kaip taikinį naudojant pilną MOG antigeną [3].
Europoje atlikto multinacionalinio tyrimo duomenimis, MOG asocijuotu recidyvų gydymas buvo veiksmingas skyrus azatiopriną, mikofenolato mofetili, rituksimabą ir ypač intraveninius imunoglobulinus, o ligą modifikuojantys vaistai, kurie standartiškai skiriami IS gydyti, šios ligos atveju buvo neefektyvūs [10].

\section{ATVEJO APRAŠYMAS}

Mergaitė susirgo būdama ketverių metų: hospitalizuota dèl sumažejusios diurezès, šlapimo retencijos ir sutrikusio vaikščiojimo. Tẻvai teigè, kad apie keletą savaičių mergaitė nenoriai rèmėsi kojomis ir pamažu nustojo vaikščioti, taip pat tapo mieguista ir irzli dienos metu. Prieš tai infekcinèmis ligomis nesirgo. Apžiūros metu mergaitė buvo sąmoninga ir bendraujanti, tačiau irzli ir išsigandusi. Pati nesistojo, pastatyta rẻmėsi abiem kojomis, tačiau verkè ir skundèsi skausmu. Palpuojant kojos buvo neskausmingos. Apžiūros metu kojose rastas sumažėjęs raumenų tonusas, normali proksimalinė jèga (apie 5 balus), nepastovi jẻgos asimetrija distaliai dešinejje (jèga - apie 4-5 balus). Sausgyslių ir antkaulio refleksai buvo pagyvėję, simetriški. Rastas teigiamas Lasego simptomas (40-30 laipsnių). Nustatytas šlapimo susilaikymas, kateterizuota šlapimo pūslè. Atlikti tyrimai. Virusinė (Epštein-Baro, enterovirusų, erkinio encefalito virusų) encefalito etiologija - atmesta, juosmeninè punkcija - be pakitimų. Autoimuninio encefalito Ak mozaika iš likvoro - neigiama, likvoro baltymų elektroforezè - intratekalinès IgG sintezès nėra, antikūnų prieš branduolio antigenus (ANA) tyrimas - teigiamas. MRT: kaklinèje dalyje negalejjo būti atmestas nugaros smegenų apimties padidejimas ir difuzinis hiperintensinis signalas, stuburo kanalas neblokuotas galvos smegenyse abipus subkortikaliai baltojoje medžiagoje, giliojoje baltojoje medžiagoje, pamato branduolių srityje abipus, thalamus srityje kaireje bei corpus callosum ir tilto srityje - plačios signalo pakitimo zonos: FLAIR ir T2 hiperintensinio signalo (1 pav. A), T1 iš dalies hipointensinio signalo, be DWI restrikcijos ir kontrastinès medžiagos kaupimo. Diagnozuotas ūminis diseminuotas encefalomielitas, poūmè ligos eiga. Skirtas gydymas metilprednizolono pulsine terapija $18 \mathrm{mg} / \mathrm{kg}$ per parą, 5 dienas. Mergaitès būklè pagerėjo: pradẻjo pati šlapintis, savarankiškai vaikščioti. Tolesnis gydymas buvo tęsiamas prednizolonu, geriant $1 \mathrm{mg} / \mathrm{kg}$ per parą, po to pamažu dozę mažinant, iš viso 6 savaites. Pacientẻ jautėsi gerai, nusiskundimų nebuvo. Siekiant ịvertinti ligos eigą, MRT buvo kartojamas kas 3 mènesius.

Po 3 mėnesių nuo ligos pradžios galvos ir kaklo MRT: buvę pokyčiai regresavo (1 pav. B), tačiau atsirado naujų pakitimų ties dešinès pusès $n$. opticus, chiasma, substantia perforata anterior sritimis (2 pav.), neintensyvus kontrastinès medžiagos kaupimas. Stuburo kaklinè dalis buvo be pakitimų. Pacientei pakartotas metilprednizolono pulsterapijos 5 dienų kursas.

Po 6 ménesių nuo ligos pradžios atliktas galvos ir stuburo MRT: buvę pakitimai regresavo, tačiau atsirado naujų pakitimų ties kairès pusès $n$. opticus, chiasma, abiem 

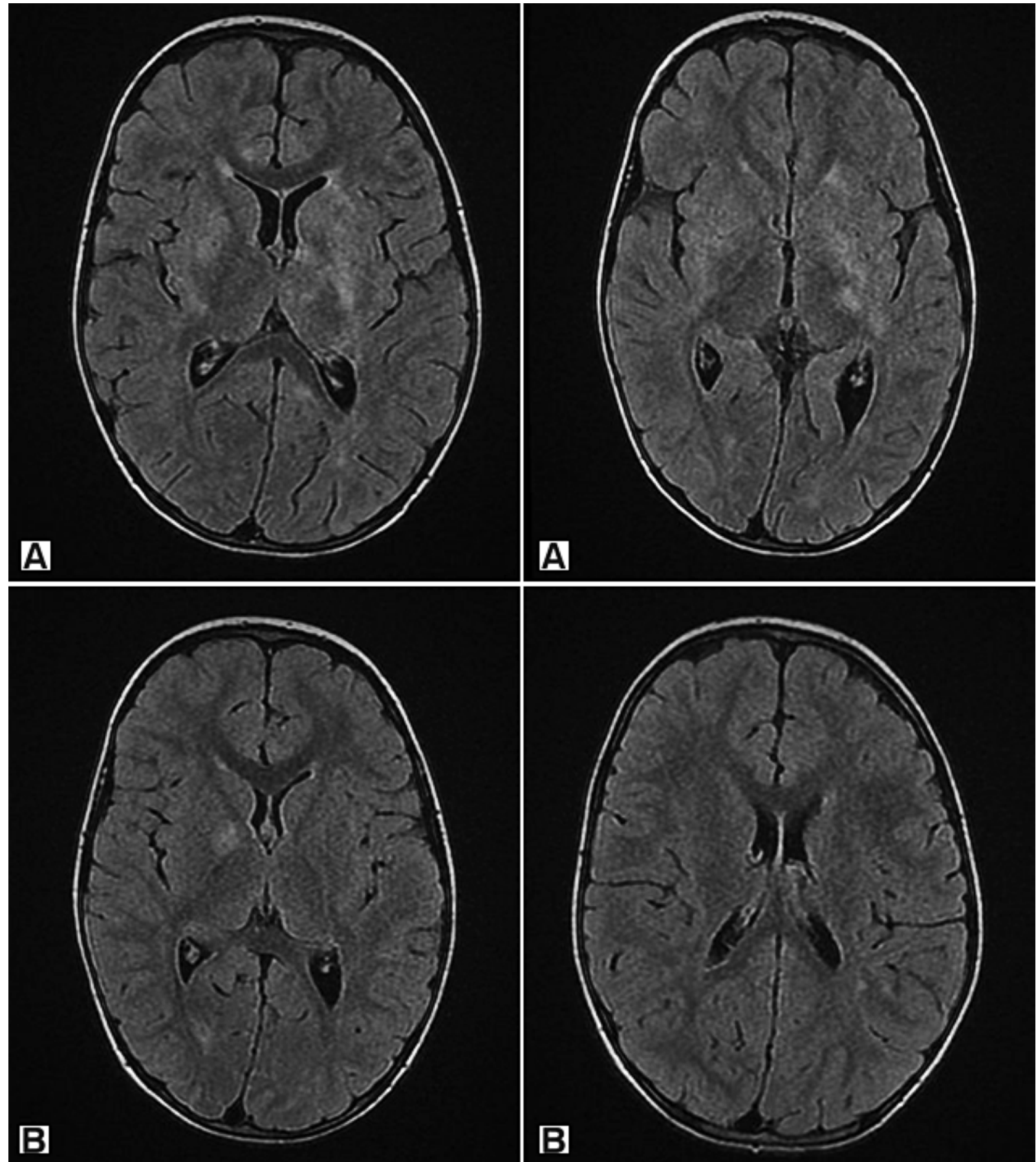

1 pav. Pacientės galvos MRT tyrimas

A. T2 sekoje galvos smegenyse abipus subkortikaliai baltojoje medžiagoje, giliojoje baltojoje medžiagoje, pamato branduolių srityje abipus, thalamus srityje kaireje bei corpus callosum ir tilto srityje plačios signalo pakitimo zonos.

B. Pakitimai giliojoje baltojoje medžiagoje, pamato branduolių srityje, thalamus srityje kairèje bei corpus callosum ir tilto srityje regresavo.

mamiliariniais kūnais, ir substantia perforata anterior sinistra srityje bei didelis $26 \times 26$ mm židinys dešiniojo smegenėlių pusrutulio baltojoje medžiagoje ( 3 pav.), neintensyvus kontrasto kaupimas chiasmos kairėje pusėje. ANA tyrimas išliko teigiamas. Atliktas degranuliacijos testas hemofagocitinès limfohistiocitozès (HLH) diferencinei diagnostikai - neigiamas. Autoantikūnų akvaporino tyrimas - neigiamas. Hospitalizacijos metu neurologinès židininès simptomatikos nebuvo, regos sutrikimo nerasta. Skirtas gydymas metilprednizolonu $18 \mathrm{mg} / \mathrm{kg}$ per parą,
5 dienas. Namuose tęstas gydymas prednizolonu $1 \mathrm{mg} / \mathrm{kg}$ per parą 6 savaites (mažinant pagal schemą).

Praẻjus 8 mèn. nuo ligos pradžios, gautas MOG antikūnų tyrimo rezultatas - nustatyti teigiami aukšti antikūnų titrai: 2500 (Innsbruko universiteto klinikose, prof. M. Reindl). Tą patị mẻnesį, konsiliumo metu, nutarta skirti gydymą intraveniniu imunoglobulinu ( $2 \mathrm{~g} / \mathrm{kg}$ kursas, skiriamas per 5 dienas), lašinant stacionare kas mėnesį, iš viso 5 kartus. Pakartojus MOG antikūnų tyrimą po 4 mėnesių, titrai išliko aukšti. 

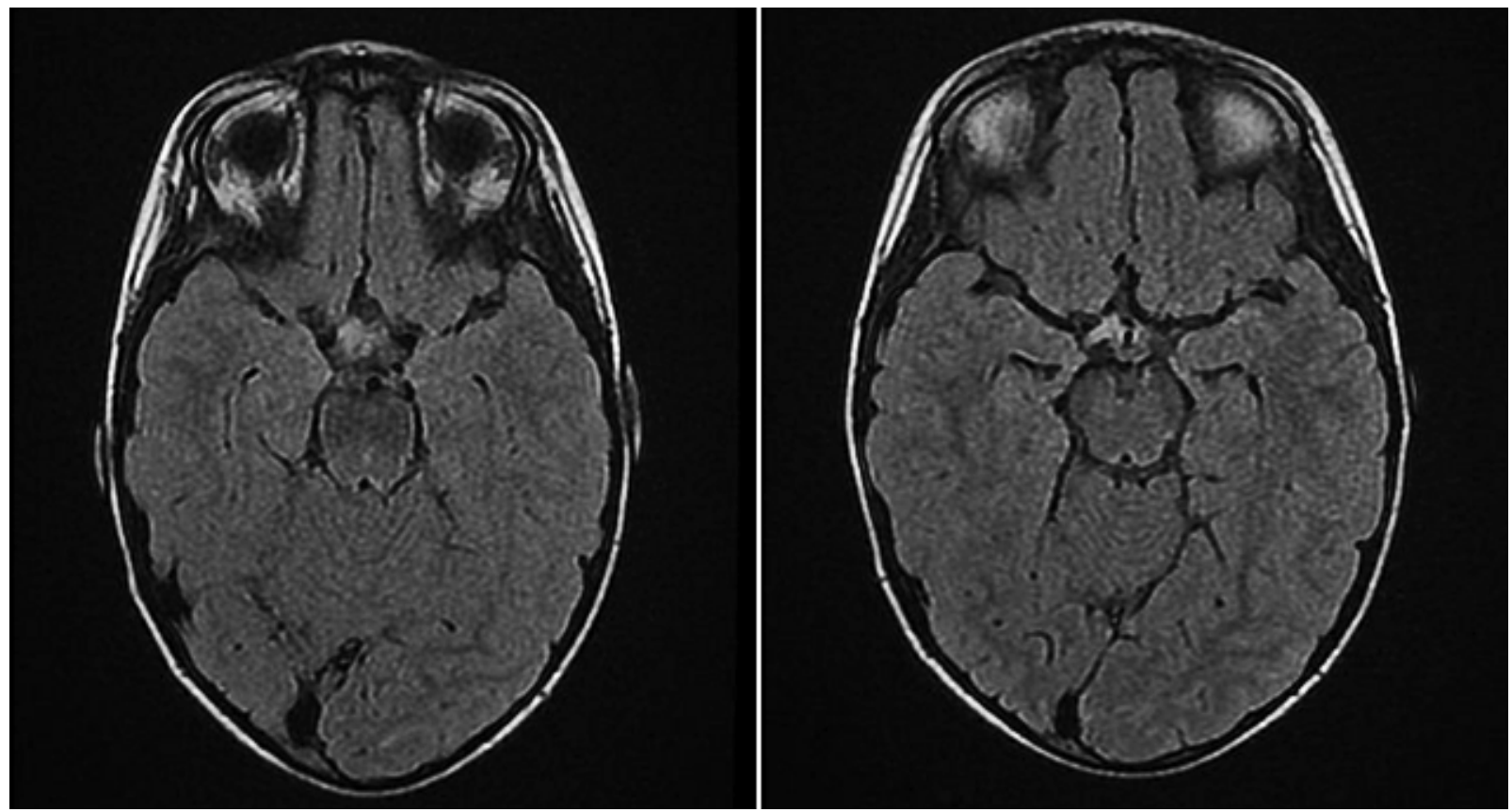

2 pav. Pacientės galvos MRT tyrimas FLAIR-T2

Pakitimai ties dešinės pusės $n$. opticus, chiasma, substantia perforata anterior srityse - Flair ir T2 sekoje hiperintensinis signalas. N. opticus dex. prechiasminė dalis ir chiasmos srityje sustorëjęs iki 5,8 $\mathrm{mm}$ (kairéje pusėje - 3,2 $\mathrm{mm}$ ).
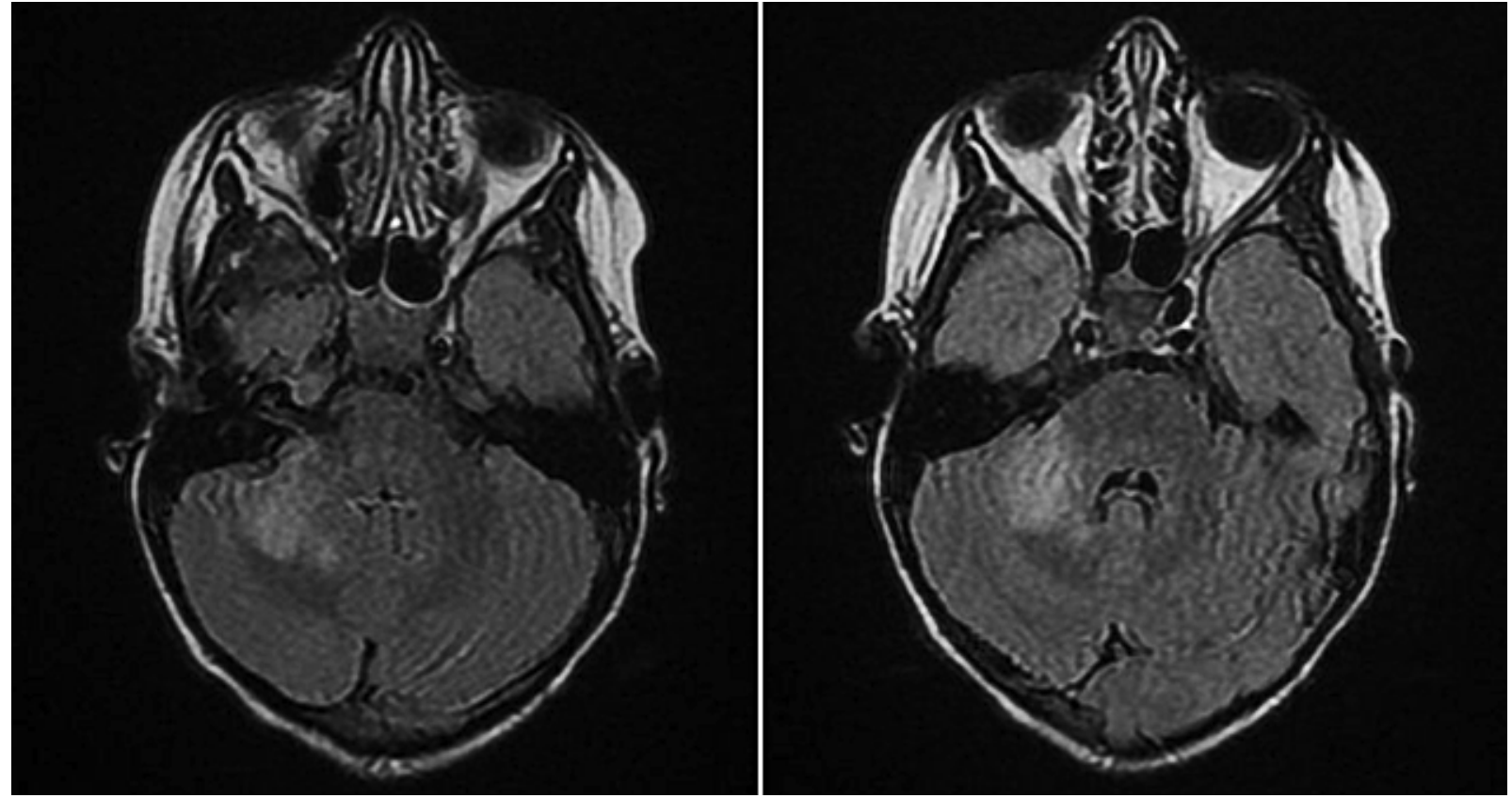

3 pav. Pacientès galvos MRT tyrimas FLAIR-T2

Atsirado naujas didelis $26 \times 26 \mathrm{~mm}$ židinys dešiniojo smegenèlių pusrutulio baltojoje medžiagoje.

Po pusantrų metų nuo ligos pradžios atliktame MRT: naujų hiperintensinio signalo židinių dinamikoje neišryškèjo. Buvę židiniai - mažèjantys. Matomi daugybiniai, nedideli, hiperintensiniai židiniai subkortikaliai ir periventrikuliariai. Dešiniajame smegenèlių pusrutulyje esantis hiperintensinio MR signalo židinys dinamikoje mažesnis. Mergaitè tebesijautė gerai, klinikinių simptomų nebuvo.

Praejus 5 mėnesiams nuo intraveninio imunoglobulino kurso pabaigos, pacientès šeima kreipèsi ị ligoninę dèl li- gos paūmejjimo - mergaitė tapo irzlesnè, nervingesnė, apie 2 mėnesius skundèsi padidejusiu mieguistumu ir papildomai miegojo dieną. Apžiūros metu buvo stebimas horizontalus nistagmas ir opsoklonusas. Atliktas MRT: lyginant su ankstesniais tyrimais, stebima neigiama dinamika (daug naujų židinių supra- ir infratentoraliai) be aktyvumo požymių. Ligos paūmèjimų profilaktikai skirtas mikofenolato mofetilis. Be to, nuspręsta skirti 1 metų trukmès gydymo kursą intraveniniu žmogaus imunoglobulinu infuzijomis po $2 \mathrm{~g} / \mathrm{kg}$ kas mènesị. 


\section{APTARIMAS}

MOG asocijuotų ligų diferencinè diagnostika gali būti labai sudètinga dèl ryškių, ligai specifinių klinikinių ir radiologinių požymių nebuvimo. Norėdami atskirti MOG asocijuotus susirgimus, turime gerai žinoti, kada reikalingi MOG-IgG testai ir kokie yra diagnostikos kriterijai. Pirmosios atakos pasireiškimas būna skirtingas, tačiau dažniausiai pasireiškia ŪDEM (52 \%), optinis neuritas (40\%), vizualiniai simptomai $(53,9 \%)$, encefalopatija (52\%) ir traukuliai $(32,8 \%)$ [10]. Pirmosios atakos požymiai yra nespecifiški ligai, todèl, atliekant diferencinę diagnostiką, svarbu MOG asocijuotus susirgimus skirti nuo IS ir optinio neuromielito (neuromielitis optica, NMO) [11].

Išsėtinė sklerozė yra lètinė, daugiapriežastinè uždegiminè liga, sukelianti CNS pažeidimus, kurie gali pasireikšti fizine ar kognityvine negalia, neurologiniais defektais [12]. Klinikinè ligos išraiška dažnai būna panaši. Būtina atskirti šias ligas, nes skiriasi gydymo taktika: ligą modifikuojantys vaistai, kurie standartiškai skiriami IS gydyti, MOG asocijuotų susirgimų atveju yra neefektyvūs [10].

Optinis neuromielitas yra uždegiminè CNS liga, pasireiškianti recidyvuojančiu optiniu neuritu ar mielitu. NMO asocijuojamas su specifiškais serumo imunoglobulinais (NMO-IgG), kurie nukreipti prieš astrocitų vandens kanalo akvaporiną-4 (AQP-4). NMO-IgG/AQP-4 antikūnai randami $80 \%$ pacientų, sergančių NMO [13].

Nors minètų ligų klinikinės manifestacijos - labai panašios, visgi yra keletas pagrindinių skirtumų, lyginant MOG asocijuotą patologiją su IS ir AQP4-IgG. MOG asocijuotai patologijai labiau būdinga vyriška lytis, jaunesnis amžius, prodrominis infekcinis sindromas ir mielitas, pasireiškiantis kaip ŪDEM komponentas. Vertinant MRT, MOG susirgimui daugiau būdingi T2 signalo pakitimai, apriboti pilkojoje medžiagoje (sagitalinės linijos ir ašinis $\mathrm{H}$ ženklas) ir nekaupiantys kontrasto gadolinio. Longitudinalinių plačių pakitimų dažnis yra vienodas tarp MOG-IgG mielito ir AQP4-IgG mielito, tačiau MOG mielitui labiau būdingi daugialypiai nugaros smegenų pažeidimai. Smegenų kūgio įtraukimas yra dažnesnis MOG-IgG negu AQP4-IgG, tačiau, lyginant su IS, dažnis reikšmingai nesiskiria [9].

Aprašomos pacientės ligos pasireiškimas atitiko MOG asocijuotai patologijai būdingą ŪDEM simptomatiką, kuria remiantis pagrịsta poūmès eigos ŪDEM diagnozé. MRT rasti daugybiniai išsiseję demielinizaciniai pakitimai galvos smegenyse, smegenų kamiene; kaklinėje dalyje itartas nugaros smegenų apimties padidejjimas, hiperintensinis signalas abipus.

Pakartojus galvos MRT po 3 mèn., buvę pokyčiai regresavo, tačiau atsirado naujų pakitimų ir neintensyvus kontrastinès medžiagos kaupimas.

Diferencinė diagnostika buvo tęsiama. Išsètinei sklerozei diagnozuoti duomenų nepakako: nors pacientei buvo randamas pažeidimų išplitimas laike ir erdvejje, tačiau ligos pasireiškimo amžius buvo netipiškas IS, likvoro baltymų elektroforezèje intratekalinės IgG sintezès nerasta, taip pat buvo nustatyti teigiami aukšti MOG antikūnų titrai, kurie nebūdingi IS.
Aprašomai pacientei pakartojus galvos MRT po 3 mèn., atsirado naujų pakitimų ties dešinès pusès $n$. opticus, chiasma, substantia perforata anterior sritimis ir neintensyvus kontrastinės medžiagos kaupimas, stuburo kaklinès dalies pakitimų neberasta. Remiantis šiais pokyčiais, buvo itartas optinis neuromielitas, tačiau ligai diagnozuoti duomenų nepakako: akvaporino autoantikūnų IgG/AQP-4 tyrimas buvo neigiamas, be to, nebuvo klinikinio ligos paūméjimo - regos sutrikimo ir mielito klinikinių simptomų.

Tolimesnè ligos eiga pasižymėjo tuo, kad kliniškai pablogėjimų nebuvo stebima apie 1,5 metų, tačiau, kartojant MRT, stebèta aktyvi ir neigiama ligos dinamika: buvę židiniai sumažėdavo arba išnykdavo, tačiau atsirasdavo nauju pažeidimų smegenyse. Dèl šios priežasties neigiami pokyčiai MRT buvo vertinti kaip ligos paūmėjimai ir skirti pakartotiniai gydymo kursai steroidais, o vèliau - intraveniniu imunoglobulinu. Duomenų apie asimptomị ligos progresavimą nėra daug. S. Jarius su bendraautoriais nurodo, kad tarp aprašytų 15 pacientų, sergančių MOG asocijuota liga, pasireiškiančia smegenų kamieno simptomatika, dviejų atvejų ligos eiga buvo subklinikinè [14].

MOG asocijuotos ligos dažnai atsinaujina, recidyvo rizika yra susijusi su pakartotinai randamais išliekančiais aukštais MOG antikūnų titrais [15]. Tai patvirtina pacientès atvejis, nes jos MOG antikūnų titras, pakartojus tyrimą po 4 mėnesių, išliko aukštas.

Vertinant gydymo efektą ir ligos dinamiką MRT, aišskèja, kad steroidai nebuvo pakankamai efektyvūs. Aprašomai pacientei pirmiausia buvo skirtas gydymas steroidais, kuris buvo efektyvus klinikinès būklès prasme - simptomai išnyko. Visgi, mažinant dozę ar nutraukus gydymą steroidais, vaikams paprastai pasireiškia ligos recidyvas [16]. Šis atvejis ypatingas tuo, kad klinikinių simptomų recidyvo nebuvo, ligos progresavimą buvo galima stebèti tik MRT vaizduose. Vertinant pacientei skirto intraveninio imunoglobulino efektą, buvo stebima ryškesnè smegeny židinių regresija MRT. Vis dèto, liga atsinaujino po 5 mènesius trukusio intraveninių imunoglobulinų kurso pabaigos, tąkart stebètas ir klinikinis ligos recidyvas bei neigiama smegenų židinių dinamika MRT. Kitos gydymo galimybès yra azatioprinas, mikofenolato mofetilis, rituksimabas $[10,17]$. Pacientès ligos paūméjimų profilaktikai buvo skirtas mikofenolato mofetilis.

Apibendrinant, pacientès klinikinè ligos eiga buvo netipinè; net ir nesant klinikinio ligos paūmèjimo, buvo būtina stebèti ligos dinamiką kartojant MRT; gydant recidyvuojančios eigos anti-MOG asocijuotą encefalomielitą, intraveninis imunoglobulinas buvo efektyvesnis už steroidus, tačiau 5 mėnesiu gydymo kursas buvo per trumpas.

\section{Literatūra}

1. Weber MS, Derfuss T, Metz I, Brück W. Defining distinct features of anti-MOG antibody associated central nervous system demyelination. Therapeutic Advances in Neurological Disorders 2018; 11: 1756286418762083. https://doi.org/ $10.1177 / 1756286418762083$

2. Genain CP, Cannella B, Hauser SL, Raine CS. Identification of autoantibodies associated with myelin damage in multiple 
sclerosis. Nature Medicine 1999; 5(2): 170-5. https://doi.org/10.1038/5532

3. Jarius S, Paul F, Aktas O, Asgari N, Dale RC, de Seze J, et al. MOG encephalomyelitis: international recommendations on diagnosis and antibody testing. Journal of Neuroinflammation 2018; 15(1): 134. https://doi.org/10.1186/s12974018-1144-2

4. Efendi H. Clinically isolated syndromes: clinical characteristics, differential diagnosis, and management. Noro Psikiyatri Arsivi 2015; 52(Suppl 1): S1-11. https://doi.org/10.5152/ npa.2015.12608

5. Miller DH, Weinshenker BG, Filippi M, Banwell BL, Cohen JA, Freedman MS, et al. Differential diagnosis of suspected multiple sclerosis: a consensus approach. Multiple Sclerosis 2008; 14(9): 1157-74. https://doi.org/10.1177/ 1352458508096878

6. Ramanathan S, Dale RC, Brilot F. Anti-MOG antibody: the history, clinical phenotype, and pathogenicity of a serum biomarker for demyelination. Autoimmunity Reviews 2016; 15(4):307-24. https://doi.org/10.1016/j.autrev.2015.12.004

7. Waters P, Woodhall M, O'Connor KC, Reindl M, Lang B, Sato DK, et al. MOG cell-based assay detects non-MS patients with inflammatory neurologic disease. Neurol Neuroimmunol Neuroinflamm 2015; 2(3): e89. https://doi.org/10.1212/NXI.0000000000000089

8. Jurynczyk M, Messina S, Woodhall MR, Raza N, Everett R, Roca-Fernandez A, et al. Clinical presentation and prognosis in MOG-antibody disease: a UK study. Brain 2017; 140(12): 3128-38. https://doi.org/10.1093/brain/awx276

9. Dubey D, Pittock SJ, Krecke KN, Morris PP, Sechi E, Zalewski NL, et al. Clinical, radiologic, and prognostic features of myelitis associated with myelin oligodendrocyte glycoprotein autoantibody. JAMA Neurol 2019; 76(3): 301-9. https://doi.org/10.1001/jamaneurol.2018.4053

10. Hacohen Y, Wong YY, Lechner C, Jurynczyk M, Wright S, Konuskan B, et al. Disease course and treatment responses in children with relapsing myelin oligodendrocyte glycoprotein antibody-associated disease. JAMA Neurol 2018; 75(4): 478-87. https://doi.org/10.1001/jamaneurol. 2017.4601

11. Dos Passos GR, Oliveira LM, da Costa BK, ApostolosPereira SL, Callegaro D, Fujihara K, et al. MOG-IgG-associated optic neuritis, encephalitis, and myelitis: lessons learned from neuromyelitis optica spectrum disorder. Front Neurol 2018; 9: 217. https://doi.org/10.3389/fneur.2018.00217

12. Ghasemi N, Razavi S, Nikzad E. Multiple sclerosis: pathogenesis, symptoms, diagnoses and cell-based therapy. Cell J 2017; 19(1): 1-10.

13. Jarius S, Wildemann B, Paul F. Neuromyelitis optica: clinical features, immunopathogenesis and treatment. Clin Exp Immunol 2014; 176(2): 149-64. https://doi.org/10.1111/ cei. 12271

14. Oliveira LM, Apóstolos-Pereira SL, Pitombeira MS, Bruel Torretta PH, Callegaro D, Sato DK. Persistent MOG-IgG positivity is a predictor of recurrence in MOG-IgG-associated optic neuritis, encephalitis and myelitis. Mult Scler 2018; 12: 1352458518811597. https://doi.org/10.1177/ 1352458518811597

15. Jarius S, Kleiter I, Ruprecht K, Asgari N, Pitarokoili K, Borisow N, et al. MOG-IgG in NMO and related disorders: a multicenter study of 50 patients. Part 3: Brainstem involvement - frequency, presentation and outcome. J Neuroinflammation 2016; 13(1): 281. https://doi.org/ 10.1186/s12974-016-0719-z
16. Ramanathan S, Mohammad S, Tantsis E, Nguyen TK, Merheb V, Fung VSC, et al. Clinical course, therapeutic responses and outcomes in relapsing MOG antibody-associated demyelination. J Neurol Neurosurg Psychiatry 2018; 89(2): 127-37. https://doi.org/10.1136/jnnp-2017-316880

17. Jarius S, Ruprecht K, Kleiter I, Borisow N, Asgari N, Pitarokoili K, et al. MOG-IgG in NMO and related disorders: a multicenter study of 50 patients. Part 2: Epidemiology, clinical presentation, radiological and laboratory features, treatment responses, and long-term outcome. J Neuroinflammation 2016; 13(1): 280. https://doi.org/10.1186/s12974016-0718-0

\section{E. Tilindytė, I. Muliuolis, R. Samaitienė}

\section{MOG ASSOCIATED AUTOIMMUNE ENCEPHALOMYELITIS WITH ACTIVE DISEASE DYNAMIC IN IMAGING EXAMINATIONS AND MINIMAL CLINICAL MANIFESTATION}

\section{Summary}

Anti-MOG-associated encephalomyelitis is an inflammatory demyelinating disease in which auto-antibodies against myelin oligodendrocyte glycoprotein (MOG) are detected in the patient's serum. MOG spectrum disorders include the following pathologies: optic neuritis, myelitis, brain or brainstem encephalitis, and acute disseminated encephalomyelitis. Most often, the disease first manifests as acute disseminated encephalomyelitis, less often as optic neuritis. Progressive encephalopathy and multiple focal neurological symptoms are characteristic to this disease: irritability, disturbed consciousness, weakness, sensory disorders, bowel, bladder dysfunction, spasticity, hyperreflexia, positive Babinsky reflex, paresis, cerebral ataxia, cerebral neuropathy, and spinal cord dysfunction (transverse myelitis). Glucocorticoids are used for treatment and a fast response is observed in most cases. If the disease is relapsing, intravenous immunoglobulin, azathioprine, mofetil mycophenolate, and rituximab are recommended.

This case report describes a 6-year-old patient with MOG spectrum multiphase disseminated encephalomyelitis. The onset of the disease was subacute: firstly, the girl became sleepy during daytime and for a month she had a gradually increasing leg pain when standing, therefore she stopped walking. After a few more days, the girl presented with urinary retention and was admitted to the hospital. The diagnosis was confirmed by magnetic resonance imaging (MRI) of the head and neck as well as by serum MOG antibody testing. Treatment with methylprednisolone pulse therapy and prednisolone resulted in the disappearance of clinical symptoms within a few weeks. However, this treatment was not effective enough - although regression of the brain lesions was observed in the MRI, new lesions were not prevented. Relapse of the disease was observed on the repeated MRI, but no clinical symptoms appeared. For the treatment of relapse, a monthly intravenous immunoglobulin course was given 5 times in total. Treatment with intravenous immunoglobulin was more effective due to regression of the lesions and a longer disease remission. However, eventually the disease relapsed again presenting with clinical symptoms and MRI lesions, suggesting that the treatment duration was not long enough.

Keywords: autoimmune encephalomyelitis, anti-MOG associated encephalomyelitis, MOG-IgG testing, demyelinating central nervous system disease.

Gauta:

Priimta spaudai:

20190504 20190515 